Karakuş Tayşi, E. (2019). Bilgisayar destekli materyal kullanımının öğrencilerin Türkçe dersine yönelik tutumlarına etkisi. Ana Dili Eğitimi Dergisi, 7(1), 256-272.

$\begin{gathered}\text { Ana Dili Eğitimi Dergisi } \\ \text { Journal of MotherTongueEducation } \\ \text { www.anadiliegitimi.com }\end{gathered}$
Geliş/Received: 09.11 .2018 Kabul/Accepted:23.01.2019

\title{
Bilgisayar Destekli Materyal Kullanımının Öğrencilerin Türkçe Dersine Yönelik Tutumlarına Etkisi
}

\author{
ESTa KARAKUŞ TAYŞi*
}

Öz

Bu çalışmada bilgisayar destekli verilen eğitimin, Türkçe dersine yönelik tutuma etkisi araştırımıştır. Çalışma, ön test-son test kontrol gruplu modele dayanan yarı deneysel desende planlanmıştır. Ayrıca bilgisayar destekli materyal kullanımıyla ilgili görüşme tekniği kullanılarak araştırma nitel olarak da desteklenmiştir. Araştırmada, Kütahya'da bir devlet okulunda 6. sınıfta öğrenim gören 72 öğrenci ile çalışılmıştır. Çalışmanın verileri yarı yapılandırılmış görüşme formu ve Topçuoğlu Ünal ve Köse'nin (2014) geliştirdiği "Türkçe Dersine Yönelik Tutum Ölçeği” ile toplanmıştır. Deney grubunda 10 hafta boyunca öğretim programındaki konular bilgisayar destekli materyaller kullanılarak anlatılmıştır. Verilerin analizinde ilişkisiz örneklemler testi, ilişkili örneklemler $\mathrm{t}$ testi uygulanmıştır. Bilgisayar destekli materyal kullanımının Türkçe dersine yönelik tutumları olumlu yönde etkilediği tespit edilmiştir. Cinsiyet ve kendilerine ait bir bilgisayara sahip olma gibi değişkenlerine göre ise anlamlı farklılık görülmemiştir. Deney grubu öğrencileri bu materyallerle işlenen Türkçe dersinin daha eğlenceli ve etkili olduğunu ifade etmişlerdir.

Anahtar Kelimeler: Türkçe Eğitimi, Türkçe dersi, bilgisayar destekli eğitim, web 2.0

\section{The Effect of Using Computer-Assisted Materials on Students' Attitudes towards Turkish Language Arts Course}

\begin{abstract}
In the current study, the effect of computer-assisted instruction on the attitudes towards the Turkish language arts course was investigated. The current study was planned according to the quasi-experimental design built on the pretest and posttest control group model. The study was conducted on 72 sixth-grade students attending a public school in the city of Kütahya. The data of the study were collected by semi-structured interview form and "Scale of Attitudes towards Turkish Course" developed by Topçuoğlu Ünal and Köse (2014). The experimental group students were taught the topics in the curriculum by using computer-assisted materials for 10 weeks. In the analysis of the collected data, independent samples t-test and dependent sample t-test were used the results showed that the use of computer-assisted materials had a positive effect on attitudes towards Turkish language arts course. Moreover, no significant difference was found based on variables such as gender and having one's own computer. The experimental group students stated that the Turkish lesson taught through these materials was more enjoyable and effective.
\end{abstract}

Key Words: Turkish education, Turkish language arts course, computer-assisted instruction, web 2.0

\footnotetext{
* Dr. Öğr. Üye., Kütahya Dumlupınar Üniversitesi, Eğitim Fakültesi, Türkçe Eğitimi Ana Bilim Dalı, Kütahya, esra.karakus@dpu.edu.tr, ORCID: 0000-0002-4669-6686.
} 


\section{Giriş}

Teknoloji son yıllarda insan yaşamının vazgeçilmez unsurlarından biri olmuştur. Teknolojik gelişmeler tek bir alanla sınırlı kalmayıp her disiplinde ve her türlü öğrenmede işe koşulmaya başlanmıştır. Temel öznesi insan olan eğitim sisteminin de bu süreçten etkilenmemesi imkânsızdır. Bununla birlikte öğrenmenin doğasına dair öğrenilenler de her geçen gün değişmektedir ve bu bağlamda da öğrenme süreci yeniden yapılandırılmaktadır. Öğrenme sürecinin önemli unsurları olarak öğrenme ortamının zenginleştirilmesi, tekniklerin çeşitlendirilmesi ve öğrencinin yaparak, yaşayarak öğrenmesi öne çıkmaktadır. Dolayısıyla teknolojide ve eğitimde yaşanan gelişmeler eğitim teknolojileri kavramının ortaya çıkmasına neden olmuştur.

\section{Türkçe Eğitimi ve Bilgisayar Destekli Eğitim}

Bilgisayar destekli eğitim, öğrenme sürecinde bilgisayar uygulamalarının ve yazılımının etkileşimli unsurlarını, bilgisayarla sağlanabilecek her türlü ortamı öğrencilere sunmak olarak değerlendirilebilir. Son on yılda eğitim teknolojileri alanında hızlı gelişmeler yaşanmış ve bilgisayar destekli eğitim hemen her okulda kullanılan bir yöntem hâlini almıştır. Ayrıca teknolojiyle ilgili gelişmelerden haberdar olup bu teknolojileri amaca uygun kullanmak bir yetkinlik alanı olmuştur. 2018 Türkçe Öğretim Programı́nda (TÖP) diğer programlardan farklı olarak bu konu da vurgulanmış ve bazı yetkinlikler yer almıştır. Bireylerin hem ulusal hem de uluslararası düzeyde, yaşamları boyunca intiyaç duyacakları düşünülen, nitelikli öğrenciler olarak yetişmelerine fayda sağlayacak beceriler olarak değerlendirilebilecek bu yetkinlikler Türkiye Yeterlilikler Çerçevesinde (TYÇ) belirlenmiştir. Sekiz temel yetkinlikten oluşan çerçevede teknolojiyi tanıma ve kullanmaya yönelik iki yeterlilik yer almaktadır. Bunlardan ilki, hızlı bir biçimde gelişen ve hayatın her alanında karşılaşılabilecek bilim ve teknoloji alanındaki temel yetkinlikleri kapsamaktadır. İkincisi ise bilgi iletişim teknolojilerini eleştirel, güvenli ve nitelikli biçimde kullanabilmeyi ve teknolojiyi üretim sürecine de dâhil edebilmeyi destekleyen dijital yetkinliktir (TÖP,2018:4). Ayrıca programın genel amaçlarında Türkçe Dersi Öğretim Programı ile öğrencilerin basılı ya da interaktif kaynaklardan bilgiye ulaşma, ulaşılan bilgiyi sorgulama, düzenleme ve ulaşılan bilgileri üretme amacıyla kullanması amaçlanmaktadır (TÖP, 2018: 7). Öğrencilerin bu becerileri kazanmaları ve programın amaçlarına ulaşılabilmesi için eğitim-öğretim ortamında teknolojiyi kullanmaları ve deneyimlemeleri gerekmektedir.

Türkçe dersi dört temel dil becerisi ve dil bilgisiyle bir bütün olarak ele alınmakla birlikte çok yönlü bir süreci içerir. Anlama ve anlatma becerilerinin her biri ortak özellikler taşımasının yanında farklı niteliklere de sahiptir. Öğrenme ortamında bu nitelikleri vurgulamak için farklı yöntem ve teknikler kullanılması gerekir. Yöntem ve teknikler gibi çoklu materyaller de öğrenme sürecini zenginleştirecektir. Türkçe Öğretim Programı'nda (2018) öğrenme-öğretme yaklaşımı olarak çeşitliliğe 
değinilmiştir. Öğrencilerin öğrenme sürecini desteklemek ve öğretim stratejilerini zenginleştirmek için öğrenme öğretme sürecinde imkân dâhilinde bilgi ve iletişim teknolojilerinden yararlanılması gerektiği belirtilmiştir. Programda öğrencilerin bilgisayar programlarını kullanmaları için teşvik edilmesi ve ders sürecinde ve uygulamalarda görsel iletişim araçlarından faydalanılması; sunu, internet, bilgisayar, tablet, etkileşimli tahta, EBA içerikleri vb. aktif olarak kullanılması yer almıştır (TÖP, 2018:8).

Dikmen ve Tuncer'e (2018: 98) göre okullardaki etkileşimli veya akıllı tahta, projeksiyon vb. teknolojik araçların çeşitliliği artsa da bu araç ve gereçlerin ortak özellikleri genellikle bilgisayarla birlikte kullanılan teknolojiler olmalarıdır. Bu açıdan bakıldığında eğitim alanında en yaygın kullanılan teknoloji aracının bilgisayar olduğu söylenebilir. Bu doğrultuda bilgisayar destekli eğitim (BDE) öğrenme sürecinde ele alınan bir konu olmuştur. Bilgisayarın hayatımıza girip yaygınlaşması sonucu bilgisayar destekli eğitim kavramı da farklı biçimlerde tanımlanmaya başlamıştır. Tanımlar öğrenme ve öğretme faaliyetlerinde bilgisayarın kullanımına vurgu yapmakla birlikte bilgisayar destekli öğretim, bilgisayarların hem öğretim amacı hem de öğretim ortamı olarak öğrenme öğretme sürecinde kullanılarak öğrencilerle etkileşimli etkinlikler planlanması olarak tanımlanabilir|| (Erişen ve Çeliköz, 2011: 127). Bu bağlamda Milî̂ Eğitim Bakanlı̆ıının teknolojiden tüm öğrencilerin faydalanması ve eğitim-öğretim sürecinde çoklu öğrenme ortamlarının oluşturulabilmesi için başlattığı "Fırsatları Artırma ve Teknolojiyi İyileştirme Hareketi" (FATiH) projesiyle bilgisayar destekli öğretim kavramı oldukça bilinir hale gelmiştir. Nitekim öğretim ortamlarında kullanılan materyallerin niteliği ve çeşitliliği birçok açıdan fayda sağlamaktadır.

Öğretim materyali kullanımının öğrenci açısından yararları birçok çalışmada vurgulanmıştır. Bu yararlar genel olarak değerlendirildiğinde belirtilen başlıklar şunlardır: öğrenme sürecinde ilgi ve isteğin artırması, öğrenmeyi daha kolay ve anlaşılır hâle getirmesi, kalıcı öğrenmeyi desteklemesi, aktif öğrenmeyi sağlaması, bireysel öğrenmenin desteklenmesi, bireysel farklılıklara göre öğrenme seçeneği sunulması, gerçek yaşama uygun öğrenme deneyimleri sağlaması, düşünme becerilerini geliştirmesi, zaman tasarrufu sağlaması şeklinde özetlenebilir (Ovalı, 2011; Apperson, Laws ve Scepansky, 2006; Sevim ve Sayır, 2017; 2001; Lu, Lai ve Law, 2010; Knapp ve Glenn, 1996; Byrne 2009). Eğitimin hedeflediği kazanımlar; beceriler ve yeterlilikler için iyi planlanmış, amacına uygun, öğrenciyi sadece bilişsel değil duyuşsal ve psikomotor açıdan destekleyen materyallere ihtiyaç duyulmaktadır. Kablan, Topan ve Erkan (2013:1635) ders içerisinde materyal kullanımının etkililik düzeyine yönelik yaptıkları meta analiz çalışmasında materyal türüne göre en büyük etkiye sahip olanların birden fazla materyalin kullanıldığı karma materyaller olduğu sonucuna ulaşmışlardır.

Teknolojinin eğitimde kullanımı yaygınlaşıp yeni olanaklar sağlamaktadır. Bununla birlikte yaşanan gelişmeler teknolojinin karmaşık bir hal almasına yol açmaktadır. Bu durumda iki temel 
kavramın iyi anlaşıması gerekmektedir: Bunlardan ilki birçok disiplin tarafından da vurgulanan 21. yüzyıl becerileri; ikincisi ise Web 2.0 döneminin içeriğidir. 21. yüzyıl becerileri; tüm toplumu biçimlendiren ve toplumsal değişim sürecinde etkili olan kavramları kapsamaktadır. Farklı biçimlerde sınıflandırılmakla birlikte beceriler, topluma uyum, kariyer ve yaşam becerileri üzerine odaklanmıştır. Uluslararası Eğitim Teknolojileri Topluluğu (ISTE) tarafından bu beceriler yedi başlık altında toplanmıştır. Buna göre 21. yüzyıl becerilerine sahip bireyler, öğrenmeye yönelik öz yeterlilikleri güçlü, dijital vatandaş, bilgiyi yapılandıran, yenilikçi tasarımcı, çok boyutlu düşünen, yaratıcı, iletişim becerileri yüksek ve küresel iş birliğine dayalı çalışandır (Akt: Filiz ve Kurt, 2018).

Günümüzde okuryazarlık kavramı oldukça genişlemiş durumdadır. 21. yüzyıl becerileri içerisinde bireylerden beklenen hayatımızın her alanında karşımıza çıkan teknolojiyi de nitelikli kullanabilmek için teknoloji okuryazarlığı becerilerini kazanmalarıdır. Bu süreçte okulun ve öğretmenin üstleneceği rehber rolünün önemi büyüktür. Bu noktada ele alınması gereken diğer kavram ise Web 2.0'dır. Bilgisayar destekli eğitim faaliyetlerinde alternatif yollardan biri olan Web 2.0 teknolojileri, Web 1.0.'dan farklı olarak kullanıcıların sadece alıcı olmadığı, içerik üretebildiği, ürettikleri içerikleri paylaşabildiği, farklı kullanıcılarla iş birliği yapabildiği teknolojiler olarak ifade edilmektedir (Frankilin ve van Harmelen, 2007, Akt:Filiz ve Kurt; 2018). Çağın gerekleri neticesinde eğitim sitemindeki dönüşümü destekleyen Web 2.0 araçlarının teknolojik bir yenilik olduğu düşünülmektedir. Öğrencileri hayata hazırlamayı temel alan eğitimin içerisinde bu araçların ders içinde öğrenme ortamına, amaç ve kazanımlarına uygun bir şekilde kullanılması önemlidir (Elmas ve Geban, 2012). Web 2.0 araçlarının eğitimde nasıl kullanılabileceği üzerinde çalışmalar yapıımaktadır. Son yıllarda eğitim öğretim sürecinde kullanılabilecek Web 2.0 araçlarının niceliği ve kullanım olanaklarının çeşitliliği artmakla birlikte bu konuya yönelik sınıflandırmalar bulunmaktadır. Web 2.0 teknolojileri içinde farklı kazanımlar için kullanılabilecek birçok uygulama mevcuttur. Bu uygulamaların bir kısmı Facebook, Youtube, twitter, kitlesel açık çevrimiçi ders platformları, akademiler, bloglar gibi çevrimiçi araçlar olmakla birlikte kullanıcıların kendi içeriklerini oluşturmalarını ve bu içerikleri elektronik ortamda paylaşmalarına olanak sağlayan (O'Reilly, 2007) programları da kapsamaktadır. Toplumda yaşanan değişim ve gelişimler eğitim sisteminin de belirleyici unsurlarındandır. Dolayısıyla sistem içerisinde nitelikli bilgiye ulaşan ve bilgi üretebilen öğrenciler yetiştirmek için bilgisayar ya da teknoloji destekli eğitim planlamaları yapılmalıdır.

Alan yazındaki çalışmalar incelediğinde Türkçe eğitimi ve bilgisayar destekli öğretim süreçleriyle ilgili sınırlı sayıda çalışmaya ulaşıımıştır. Araştırmalardan ikisinin becerilere birinin Türkçe öğretimine yönelik olduğu görülmüştür. Ovalı (2011) 8. sınıf öğrencileriyle yürüttüğü deneysel çalışmasında bilgisayar destekli öğretimin öğrencilerin anlama becerisine etkisini belirlemeyi amaçlamıştır. Sevim ve Sayır (2017) durum çalışması olarak planladıkları araştırmalarında akıllı tahta 
kullanılarak sürdürülen konuşma becerisi etkinlikleriyle ilgili öğretmenlerden ve öğrencilerden görüş almışlardır. Tayfa (2018) öğrencilerin akademik başarılarında, Türkçe dersine ve Türkçe dersinde akıllı tahta kullanmaya yönelik tutumlarında etkileşimli tahta kullanımını araştırmıştır. Ayrıca Benzer (2017) “Dijital Çağda Öğretim Teknolojileri ile Türkçe Eğitimi” adlı kitabında bilgisayar destekli programların Türkçe eğitiminde genel bir sınıflandırmayla nasıl kullanılabileceğini belirtmiştir. Sınırlı araştırma bulunan bu alanda benzer bir çalışmanın bulunmaması, eğitim ve teknolojinin iç içe geçtiği günümüz koşullarında alana katkı sağlayacağı düşüncesiyle çalışmada, ortaokul 6. sınıf öğrencilerinin Türkçe dersine yönelik tutumlarında bilgisayar destekli materyal kullanımının etkisini incelemek amaçlanmıştır. Bu doğrultuda aşağıdaki sorulara cevap aranmıştır:

1. Bilgisayar destekli materyal kullanılarak Türkçe dersi işlenilen deney grubu öğrencileriyle sadece ders kitabı etkinliklerine dayalı ders işlenilen kontrol grubu öğrencilerinin Türkçe dersine yönelik tutumları arasında anlamlı farklılık var mıdır?

2. Deney grubundaki öğrencilerin ön-son test puanları arasında anlamlı farklılık var mıdır?

3. Kontrol grubundaki öğrencilerin ön-son test puanları arasında anlamlı bir farklılık var mıdır?

4. Deney grubunun ön test-son test puanlarında cinsiyet ve kendilerine ait bilgisayara sahip olma değişkenine göre anlamlı bir farklııı var mıdır?

5. Türkçe derslerinde bilgisayar destekli materyal kullanımına yönelik öğrenci görüşleri nelerdir?

\section{Yöntem}

\section{Araştırmanın Modeli}

Bilgisayar destekli öğrenme ortamının Türkçe dersine yönelik tutumlara etkisinin araştırıldığı bu çalışmada nicel araştırma yöntemlerinden ön test-son test kontrol gruplu yarı deneysel desen kullanılmıştır. Bu model, değişkenlerin hepsinin kontrol altına alınamayacağı durumlarda özellikle de eğitim alanında yapılan çalışmalarda en çok tercih edilen desendir çünkü deneysel desenlerde uygulanan yansız atama yoluyla (random) grup oluşturma imkânı eğitim araştırmalarında pek mümkün olmamaktadır çünkü araştırmacı deneysel bir çalışma için yapay gruplar oluşturamaz var olan gruplardan seçim yapar. Bu gruplardan biri deney diğeri ise kontrol grubu olarak çalışma sürecine başlanır. Her iki grupta da uygulama öncesi ve sonrası ölçümler yapılır (Karasar, 2005:97; Creswell, 2003, 2005; Clark ve Creswell, 2007; Balcı, 2001; Büyüköztürk, 2001). Araştırma için 6. sınıfta öğrenim gören birbirine denk (akademik başarı, öğrenci sayısı vb.) iki farklı sınıf seçilmiştir. Bunlardan biri deney, biri kontrol olarak seçkisiz atamayla belirlenmiştir. Uygulamanın öğrenciler 
üzerindeki etkisini öğrenmek için nitel araştırma tekniklerinden görüşme kullanılmıştır. Veriler yarı yapılandırılmış görüşme formlarıyla toplanmıştır.

\section{Araştırma Grubu}

Araştırmanın çalışma grubu 2017-2018 eğitim öğretim yılında Kütahya il merkezinde devlete bağı̆ bir ortaokulda 6.sınıfta öğrenim gören 72 öğrenciden oluşmaktadır. Araştırma grubunun demografik özellikleri Tablo 1'de gösterilmiştir.

Tablo 1. Deney ve Kontrol Gruplarının Cinsiyete Göre Dağılımı

\begin{tabular}{lccc}
\hline Grup & KIz & Erkek & Toplam \\
\hline Deney & 18 & 17 & 35 \\
\hline Kontrol & 20 & 17 & 37 \\
\hline Toplam & 38 & 34 & 72 \\
\hline
\end{tabular}

Deney grubunda 18 kız, 17 erkek; kontrol grubunda 20 kız, 17 erkek öğrenci vardır. Araştırma toplam 72 öğrenciyle yürütülmüştür. Bunlardan $38^{\prime} i$ kız, 34'ü erkektir. Deney ve kontrol gruplarındaki öğrencilerin sayıları denklik sağlamaktadır.

Araştırmaya katılacak öğrencilerin Türkçe dersine yönelik tutumları arasındaki farklılığın anlamlı olup olmadığını belirlemek için tutum ölçeği uygulanmıştır. Elde edilen verilere ilişkisiz örneklemler $\mathrm{t}$ testi yapılmış ve sonuçlar Tablo 2 'de verilmiştir.

Tablo 2. Deney ve Kontrol Grubu Öğrencilerinin Türkçe Dersine Yönelik Tutum Ölçeği Ön Test Puanlarına Ilişsin ilişkisiz Örneklemler t Testi Sonucu

\begin{tabular}{|c|c|c|c|c|c|c|c|}
\hline & Grup & $\mathrm{N}$ & $x$ & $S$ & $\mathrm{sd}$ & $\mathrm{t}$ & $p$ \\
\hline \multirow[t]{3}{*}{ 1. Faktör } & Deney & 35 & 58,45 & 10,43 & 70 &,- 700 & ,486 \\
\hline & Kontrol & 37 & 60,08 & & & & \\
\hline & & & & 9,23 & & & \\
\hline \multirow[t]{3}{*}{ 2.Faktör } & Deney & 35 & 32,22 & 5,30 & 70 & $-1,14$ & 163 \\
\hline & Kontrol & 37 & 34,16 & & & & \\
\hline & & & & 6,26 & & & \\
\hline \multirow{2}{*}{ 3.Faktör } & Deney & 35 & 16,45 & 3,34 & 70 & $-1,20$ & ,232 \\
\hline & Kontrol & 37 & 17,35 & 2,95 & & & \\
\hline \multirow[t]{2}{*}{ Toplam } & Deney & 35 & 96,48 & 15,23 & 70 & $-1,26$ & 283 \\
\hline & Kontrol & 37 & 100,78 & 13,74 & & & \\
\hline
\end{tabular}


Tabloda deney ve kontrol grubunda yer alan öğrencilerin ön testten aldıkları puanların ortalamaları görülmektedir. Buna göre deney ve kontrol grubu öğrencilerinin Türkçe dersine yönelik tutumları arasında anlamlı bir farklııı̆ın $[t(70)=1.26, p>.05]$ olmadığı tespit edilmiştir. Her faktör için ayrı yapılan analizlerde de farkın anlamlı olmadığı görülmüştür. Bu sonuçlara göre deney ve kontrol grupları öğrencilerinin uygulamadan önceki puanlarının birbirine eşit olduğu söylenebilir.

\section{Veri Toplama Araçları}

Araştırmada öğrencilerin Türkçe dersine yönelik tutumlarını tespit etmek için 2014 yılında Topçuoğlu Ünal ve Köse (2014)'nin geliştirmiş olduğu “Türkçe Dersine Yönelik Tutum Ölçeği” kullanılmıştır. Beşli likert tipinde hazırlanan 27 maddelik ölçeğin Cronbach Alfa katsayısı .915'tir. Bu araştırmada güvenirlik katsayısı .89 bulunmuştur. Ölçek toplam varyansın \%52,746'sını karşılamaktadır. Maddelerin faktör yük değerleri .791 ile .474 arasındadır. Birinci faktörde 18, ikincide 8 ve üçüncüde 4 madde bulunmaktadır. 3 boyutlu ölçeğin birinci alt boyutu derse yönelik ilgi ve sevgi; ikincisi derse ilişkin olumsuz tutumlar; üçüncü alt boyut ise derse yönelik etkinlikler olarak adlandırılmıştır. Ölçeğin kullanımı için ölçek sahibinden izin alınmıştır.

Öğrencilerin uygulama süreciyle ilgili görüşlerini almak için yarı yapılandırılmış görüşme formu kullanılmıştır.

\section{Verilerin Toplanması}

Veriler üç aşamada toplanmıştır. Deney ve kontrol gruplarına deneysel işlem öncesi "Türkçe Dersine Yönelik Tutum Ölçeği" uygulanmıştır. Deney grubunda 10 hafta boyunca öğretim programındaki konular bilgisayar destekli materyallerle desteklenerek anlatılmıştır. Sürecin sonunda "Türkçe Dersine Yönelik Tutum Ölçeği" iki gruba da tekrar uygulanmıştır. Üçüncü aşamada da deney grubu öğrencileriyle görüşme yapılarak süreçle ilgili görüşleri alınmıştır. Konular, öğretmenin yıllık planına uygun olarak hem konu anlatımını destekleyici hem de değerlendirmeyi sağlayacak şekilde tasarlanmıştır. Süreçte power point, wisemapping (zihin haritası yapımı), padlet (pano oluşturma), canva (poster oluşturma), make beliefs comix (karikatür oluşturma), pixton (hikâye oluşturma), flippquiz (test hazırlama), puzzlemaker (bulmaca oluşturma), kahoot (test hazırlama) programları kullanılmış, bunlar bazı haftalarda iki boyutlu materyallerle de desteklenmiştir.

\section{Verilerin Analizi}

Verilerin analizinde hangi istatistik testlerinin kullanılacağını belirlemek için normallik testleri yapılmıştır. Büyüköztürk (2011) grup büyüklüklerinin 50'den küçük olduğu durumlarda ShapiroWilks, büyük olduğunda da KolmogorovSmirnov testlerinin kullanılacağını belirtmektedir. Grupların öğrenci sayılarının 30'dan büyük olması sebebiyle araştırmada KolmogorovSmirnov testi uygulanmış ve dağılımın normal olduğu tespit edilerek parametrik testler kullanılmıştır. Deney ve kontrol grupları 
arasındaki ilişkiyi belirlemek için ilişkisiz örneklemler $\mathrm{t}$ testi, grupların kendi içindeki ilişkisini analiz etmek için de ilişkili örneklemler $t$ testi uygulanmıştır.

\section{Bulgular}

Bu bölümde bulgular verilerin istatistiksel analize dayalı olarak alt problemlerdeki sıraya göre verilmiştir. Araştırmanın birinci alt problemine bağıı olarak bilgisayar destekli materyal kullanılarak Türkçe dersi işlenilen deney grubu öğrencileri ile ders kitabı etkinliklerine dayalı ders işlenilen kontrol grubu öğrencilerinin Türkçe dersine yönelik tutumlarında farklılık olup olmadığı incelenmiştir. İlgili veriler Tablo 3'te sunulmuştur:

Tablo 3. Deney ve Kontrol Grubu Öğrencilerinin Türkçe Dersine Yönelik Tutum Ölçeği Son Test Puanlarına Ilişkin ilişkisiz Örneklemler t Testi Sonuçları

\begin{tabular}{|c|c|c|c|c|c|c|c|}
\hline & Grup & $\mathrm{N}$ & $x$ & $S$ & $\mathrm{sd}$ & $t$ & $p$ \\
\hline \multirow[t]{2}{*}{ 1. Faktör } & Deney & 35 & 61,82 & 8,61 & 70 & 5,02 & ,000 \\
\hline & Kontrol & 37 & 52,49 & 7,11 & & & \\
\hline \multirow[t]{2}{*}{ 2.Faktör } & Deney & 35 & 33,11 & 4,72 & 70 & 3,84 & ,000 \\
\hline & Kontrol & 37 & 28,70 & 5,00 & & & \\
\hline \multirow[t]{2}{*}{ 3.Faktör } & Deney & 35 & 17,57 & 2,45 & 70 & 5,90 & ,000 \\
\hline & Kontrol & 37 & 14,13 & 2,48 & & & \\
\hline \multirow[t]{2}{*}{ Toplam } & Deney & 35 & 112,51 & 14,01 & 70 & 5,86 & ,000 \\
\hline & Kontrol & 37 & 95,32 & 10,74 & & & \\
\hline
\end{tabular}

Tabloda gruplara ait son test puanları verilmiştir. Bilgisayar destekli Türkçe öğretimi uygulamalarından sonra kontrol grubu puan ortalaması 10,74 iken deney grubununki 14,01'dir. Aralarındaki farkın anlamlılı̆ı için ilişkisiz örneklemler $\mathrm{t}$ testi yapılmış ve grupların son test puanları arasındaki farkın anlamlı olduğu saptanmıştır $[t(70)=5.86, p<.05]$. Ayrıca tutum ölçeğinin alt faktörlerine de bakıldığında anlamlı farklıık olduğu görülmektedir. Bu sonuçlar, öğrencilerin bilgisayar destekli materyallerle işlenen Türkçe derslerine yönelik olumlu tutum geliştirdikleri şeklinde yorumlanabilir.

1. faktör "derse yönelik ilgi ve sevgi" son test puanlarına göre deney grubunun ortalaması 61 , 82; kontrol grubunun 52,49'dur. Sonuçlara göre grupların puanları arasında deney grubunun lehine farklılık olduğu tespit edilmiştir $[t(70)=5.02, p<.05]$. Uygulama sonucunda deney grubu öğrencilerin derse ilgilerinin arttığı söylenebilir. 
2. faktör "derse ilişkin olumsuz tutumlar" son test puanlarında da anlamllık yine deney grubu lehinedir $[t(70)=3.84, p<.05]$. Uygulamalar öğrencilerin derse yönelik geliştirdikleri olumsuz tutumlarını değiştirmiştir denilebilir.

3. faktör "derse yönelik etkinlikler" son test puanlarında deney grubunun aritmetik ortalamasının 17,57; kontrol grubunun 14,13 olduğu görülmektedir. Elde edilen sonuçlar anlamlılığın deney grubu lehine olduğunu göstermektedir $[t(70)=5.90, p<.05]$. Buna göre deney grubundaki öğrencilerin Türkçe dersine yönelik etkinliklere katılmada daha olumlu tutumlara sahip oldukları söylenebilir.

Araştırmada ikinci olarak deney grubu öğrencilerinin ön ve son test puanları arasındaki farkııı̆ı belirlemek için t-testi yapılmış, veriler Tablo 4'te sunulmuştur.

Tablo 4. Deney Grubu Öğrencilerinin Türkçe Dersine Yönelik Tutum Ölçeği Ön ve Son Test Puanlarına Ilişkin ilişskili Örneklemler $t$ Testi Sonuçları

\begin{tabular}{lcccccc}
\hline Grup & $\mathrm{N}$ & $\mathrm{X}$ & $\mathrm{S}$ & $\mathrm{sd}$ & $\mathrm{t}$ & $\mathrm{p}$ \\
\hline Ön Test & 35 & 96,48 & 15,23 & 34 & 15,87 &, 000 \\
Son Test & 35 & 112,51 & 14,01 & & & \\
\hline
\end{tabular}

Bilgisayar destekli materyal kullanımının Türkçe dersine yönelik tutumlara etkisinin olup olmadığını saptamak için yapılan ilişkili örneklemler $t$ testi sonucunda, deney grubundaki öğrencilerin ön test tutum puanları ortalaması $(96,48)$ ile son test tutum puanları ortalaması $(112,51)$ arasındaki farkın anlamlı olduğu görülmüştür [t(34)=15.87, p<.05]. Bu bağlamda deney grubunda yapılan uygulamaların etkili olduğu söylenebilir.

Kontrol grubu öğrencilerinin ön ve son test tutum puanlarına yönelik veriler tablo 5 'te verilmiştir.

Tablo 5. Kontrol Grubu Öğrencilerinin Türkçe Dersine Yönelik Tutum Ölçeği Ön ve Son Test Puanlarına ilişkin ilişsili Örneklemler t Testi Sonucu

\begin{tabular}{lcccccc}
\hline Grup & $\mathrm{N}$ & $\mathrm{X}$ & $\mathrm{S}$ & $\mathrm{sd}$ & $\mathrm{t}$ & $\mathrm{p}$ \\
\hline Ön Test & 37 & 100,78 & 13,74 & 36 & $-1,99$ & 0,53 \\
Son Test & 37 & 95,32 & 10,74 & & & \\
\hline
\end{tabular}

Tabloya göre kontrol grubu öğrencilerinin ön ve son test puanları arasındaki fark anlamlı bulunmamıştır [t(36)=-1,99, p>.05]. Kontrol grubu öğrencilerinin ön test puan ortalamaları 100,78; son test de 95,32'dir. 
Araştırmada ayrıca bilgisayar destekli materyallerle yapılan Türkçe derslerinin öğrencilerin derse yönelik tutumları üzerinde etkisinin cinsiyet ve kendilerine ait bir bilgisayara sahip olma gibi değişkenlerine göre anlamlı farklılık gösterip göstermediği incelenmiştir. Bu bağlamda dördüncü alt problem olan deney grubunun ön test puanlarında cinsiyete göre farklılık gösterip göstermediği incelenmiş, sonuçlar Tablo 6'da sunulmuştur.

Tablo 6. Deney Grubu Öğrencilerinin Ön Test Puanlarının Cinsiyet Değişkenine Göre ilişkisiz Örneklemler t Testi Sonucu

\begin{tabular}{lcccccc}
\hline Cinsiyet & $\mathrm{N}$ & $\mathrm{X}$ & $\mathrm{S}$ & $\mathrm{sd}$ & $\mathrm{t}$ & $\mathrm{p}$ \\
\hline Kız & 18 & 99,44 & 12,75 & 33 & 1,18 &, 243 \\
Erkek & 17 & 93,35 & 17,33 & & & \\
\hline
\end{tabular}

Tablo 6 incelendiğinde kız öğrencilerin ön test puan ortalamalarının 99,44; erkeklerinkinin de 93,35 olduğu görülmüştür. Kız öğrencilerin tutum puanları erkeklere göre daha yüksek olmasına rağmen istatiksel açıdan anlamda bir farklılık oluşmamıştır [t(33)=1,18, $p>.05]$.

Tablo 7. Deney Grubu Öğrencilerinin Son Test Puanlarının Cinsiyet Değişkenine Göre Ilişskisiz Örneklemler t Testi Sonucu

\begin{tabular}{lcccccc}
\hline Cinsiyet & $\mathrm{N}$ & $\mathrm{X}$ & $\mathrm{S}$ & $\mathrm{sd}$ & $\mathrm{t}$ & $\mathrm{p}$ \\
\hline Kız & 18 & 114,72 & 12,62 & 33 &, 958 &, 345 \\
Erkek & 17 & 110,17 & 15,37 & & & \\
\hline
\end{tabular}

Tablo 7'deki analizlere göre kız ve erkek öğrencilerin son test puan ortalamaları arasındaki farklıı̆ın anlamlılığı belirlenmiştir [t(33)=,958, p>.05]. Son test puan ortalamaları kız öğrenciler için 114,72; erkek öğrenciler içinse 110,17 olarak hesaplanmıştır. Bu sonuçlar, uygulama sürecinin cinsiyet farkı olmadan bütün öğrencileri olumlu yönde etkilediği şeklinde yorumlanabilir.

Deney grubu öğrencilerinin ön test-son test puan ortalamalarının kendilerine ait bilgisayara sahip olma değişkenine göre farklılaşıp farklılaşmadığını tespit etmek için yapılan analizlerin sonuçları Tablo 8 ve 9'da sunulmuştur.

Tablo 8. Deney Grubu Öğrencilerinin Ön Test Puanlarının Kendilerine Ait Bilgisayara Sahip Olma Değişkenine Göre Iliş̧kisiz Örneklemler T Testi Sonucu

\begin{tabular}{lcccccc}
\hline Bilgisayar & $\mathrm{N}$ & $\mathrm{X}$ & $\mathrm{S}$ & $\mathrm{sd}$ & $\mathrm{t}$ & $\mathrm{p}$ \\
\hline Evet & 22 & 95,81 & 16,01 & 33 &,- 333 &, 741 \\
Hayır & 13 & 97,61 & 14,37 & & & \\
\hline
\end{tabular}


Öğrencilerin Türkçe dersine yönelik tutumlarında, kendilerine ait bilgisayara sahip olma değişkenine göre anlamlı bir farklılık görülmemiştir [t(33)=-333, p>.05].

Tablo 9. Deney Grubu Öğrencilerinin Son Test Puanlarının Kendilerine Ait Bilgisayara Sahip Olma Değişkenine Göre Ilişskisiz Örneklemler T Testi Sonucu

\begin{tabular}{lcccccc}
\hline Bilgisayar & $\mathrm{N}$ & $\mathrm{X}$ & $\mathrm{S}$ & $\mathrm{sd}$ & $\mathrm{t}$ & $\mathrm{p}$ \\
\hline Evet & 22 & 111,04 & 13,97 & 33 &,- 802 &, 428 \\
Hayır & 13 & 115,00 & 14,28 & & & \\
\hline
\end{tabular}

Tablo 9'a bakıldığında uygulama sürecinin öğrencilerin bilgisayara sahip olup olmama değişkenini etkilemediği görülmektedir. Bilgisayara sahip olan öğrencilerin puan ortalamasıyla $(111,04)$; olmayanların puan ortalaması $(115,00)$ arasında anlamlı bir farklılık bulunmamıştır [t(33)=$802, p>$.05]. Sonuçlara göre, sınıf ortamında bilgisayar destekli materyal kullanımı bilgisayarı olan ve olmayan bütün öğrencileri eşit düzeyde etkilemektedir denilebilir.

Öğrencilerin Türkçe derslerinde bilgisayar destekli materyal kullanımına yönelik görüşleri alınmış ve Tablo 10 'de verilmiştir. Doğrudan alıntılar verilirken öğrenciler Ö1, Ö2 biçiminde kodlanmıştır.

Tablo 10. Türkçe Derslerinde Bilgisayar Destekli Materyal Kullanımına Yönelik Öğrenci Görüşleri

\begin{tabular}{lc}
\hline Cevap & (f) \\
\hline Eğlenceli & 30 \\
\hline Öğretici & 23 \\
\hline Uzun süre yapılmalı & 17 \\
\hline Anlamayı kolaylaştırıcı & 16 \\
\hline İlgi çekici & 14 \\
\hline Akılda kalıcı & 12 \\
\hline Derse yönelik olumlu bakış açısı & 11 \\
\hline Zevkli & 8 \\
\hline Sosyalleşmeyi sağlama & 8 \\
\hline Heyecan verici & 5 \\
\hline Zihin geliştirici & 4 \\
\hline
\end{tabular}

Tabloda görüldüğü gibi uygulamayla ilgili öğrencilerin çoğu olumlu görüş bildirmiştir. Deney grubundaki öğrencilerin 30'u uygulamaların çok eğlenceli olduğunu belirtmiştir. Buna ek olarak öğretici yönüne de vurgu yapmışlardır. Öğrencilerin çoğu uygulamaların daha uzun süre devam etmesini istemiştir. 11 öğrenci derse bakış açısının olumlu yönde değiştiğini açıkça ifade etmiştir. 
Bunun yanında dersin bu şekilde daha ilgi çekici, heyecan verici, zihin geliştirici olduğunu da söylemişlerdir. Öğrenciler uygulamaların sosyalleşmelerini de sağladığını belirtmişlerdir. Öğrencilerin görüşlerinden bazıları aşağıda verilmiştir:

Ö2: Bu uygulamalarla eğlenceli bir ders oluyor Türkçe, dersten zevk almaya başladım, vakitler daha güzel geçiyor

Ö11: Bence yapılan uygulamalar daha sık olmalıdır. Çünkü materyaller hem eğlenceli hem de sosyalleşmemizi sağlıyor.

Ö17: Türkçe dersi çok eğlenceli olmaya başladı, oyunlar vb. uygulamalar çok güzel. Bu uygulamalar derse bakış açımı çok iyi etkiledi.

Ö25: Türkçe dersinde daha çok ders işlenmesini istiyorum yani 6 saat değil 8 saat olsa böyle ders işleyeceksek.

Ö30: Bence öğretilmek istenilen şeyi daha iyi kavramamıza yardımcı oluyor. Anlatılan şeyi daha iyi öğreniyoruz. Neyin nerede kullanılacağını daha güzel anlıyoruz.

Ö32: Böyle etkinliklerin daha sık yapılmasını isterim. Çünkü çok eğlenceli ve zihin geliştirici. Derse bizim daha çok ilgi vermemizi sağlıyor.

Öğrencilerin uygulama sürecine yönelik görüşlerinin olumlu yönde olması yapılan uygulamaların etkili olduğu ve Türkçe dersine olan bakış açısının olumlu olarak değişme gösterdiği biçiminde yorumlanabilir.

\section{Tartışma, Sonuç ve Öneriler}

Bu araştırmada ortaokul 6. Sınıf öğrencilerinin Türkçe dersine yönelik tutumlarında bilgisayar destekli materyal kullanımının etkisi incelenerek bu doğrultuda öğrencilerin tutumlarında cinsiyete ve kendilerine ait bilgisayara sahip olma durumlarına göre anlamlı farklılık oluşup oluşmadığını tespit etmek amaçlanmıştır. Ayrıca öğrencilerin bilgisayar destekli materyal kullanımına yönelik görüşleri alınmıştır. Bu kapsamda araştırmada öğrencilerin bilgisayar destekli materyallerle işlenen Türkçe derslerine yönelik olumlu tutum geliştirdikleri sonucuna ulaşıımıştır. Buna göre öğrenme sürecinde bilgi ve iletişim teknolojilerinin kullanılması öğrencilerin ilgilerini çekmekte ve meraklarını uyandıııı nitelikler taşımaktadır ayrıca bu programlarla aktif katılımın sağlaması yapılan araştırmada öğrenenlerin derse ilgi göstererek derse yönelik olumlu tutum geliştirmelerinde bilgisayar destekli teknolojilerin kullanılmasının etkili olduğunu düşündürmektedir. Araştırma sonuçları benzer çalışmalarla da örtüşmektedir (Olgun, 2006; Tataroğlu, 2009; Ovalı, 2011; Güven ve Sülün, 2012; Tercan, 2012; Gençoğlu, 2013; Koç, Şimşek ve Has, 2013; Tiryaki; 2014). Ovalı, 8. sınıf öğrencileriyle 
gerçekleştirdiği çalışmasında bilgisayar destekli Türkçe derslerinin öğrencilerin anlama becerisine etkisini tespit etmeyi amaçlamıştır. Araştırma sonucunda bilgisayar destekli öğretimin yapıldığı deney grubu lehine anlamlı bir farklılık belirlenmiştir. Diğer bir ifadeyle bilgisayar destekli eğitim öğrencilerin Türkçe dersine yönelik geliştirdikleri tutumlarını olumlu olarak değiştirmiştir. Benzer şekilde bilgisayar destekli öğretimin öğrencilerin matematik dersine yönelik tutumlarını (Tataroğlu,2009), fen ve teknoloji dersine yönelik tutumlarını (Tercan, 2012; Güven ve Sülün, 2012; Koç, Şimşek ve Has, 2013; Tiryaki; 2014) anlamlı biçimde değiştirdiğini ifade eden çalışmalar mevcuttur. Bununla birlikte Gençoğlu (2013), Şen (2013), Önder (2015) ve Tayfa (2018) yaptıkları çalışmalarda deney ve kontrol grubunun derse yönelik son tutumlarında istatistiksel olarak anlamlı bir fark olmadığını belirtmiştir. Tayfa (2018) Türkçe derslerinde etkileşimli tahta kullanımıyla ilgili yürüttüğü çalışmasında etkileşimli tahta ile öğretimin yapıldığı deney grubunun uygulama sonrasında tutum ölçeğinden aldığı puan ortalamasının uygulama öncesinde aldığı puan ortalamasından daha yüksek olduğu sonucuna ulaşmıştır. Yükselen puanlar istatistiki olarak anlamlı bulunacak düzeyde olmasa da araştırma sonucunda Türkçe dersinde etkileşimli tahta kullanımının öğrencilerin Türkçe dersine yönelik tutumunu artırdığı belirtilmiştir. Sevim ve Sayır (2017) akıllı tahtanın konuşma becerisi etkinliklerinde kullanımına yönelik aldıkları görüşler doğrultusunda öğrencilerin çok büyük bir kısmının akıllı tahta kullanımının derslere olan ilgiyi ve katılımı arttırdığını düşündüklerini tespit etmişlerdir. Bu çalışmada da öğrenciler yapılan uygulamalarla dersi daha ilgiyle dinlediklerini ve dersten zevk aldıklarını ifade etmişlerdir. Aynı zamanda anlamalarını kolaylaştırıp akılda kalıcılığı sağladığını belirtmişlerdir. Keser'e göre de (1988) bilgisayar destekli eğitim, farklı hızlarda öğrenen öğrencileri destekleyen bir öğrenme ortamı oluşturur; anlaşılmayan yerlerin tekrar edilebilmesi, öğrenme sürecinin önemli bir ögesi olarak dönütün hemen verilebilmesi, birden fazla cevaplama olanağı sağlaması, derse olan ilgiyi üst düzeyde tutması, zaman ve emek açısından ekonomik olması ve öğrencinin dikkatini uzun süre çekerek öğrenme motivasyonu oluşturması bakımından faydalıdır (Akt: Dikmen ve Tuncer, 2018). Araştırma sonuçları ve elde edilen nitel bulgulara bu açılardan bakıldığında, öğrencilerin BDE materyallerinden öğrenme sürecinde olumlu olarak etkilendikleri görülmektedir. Tutumlar çok yönlü ve karmaşık olmaları ve ayrıca bilişsel, duyuşsal ve psikomotor özellikleri nedeniyle hızlı değişim göstermeyebilirler. Ancak elde edilen bulgular ışığında bilgisayar destekli eğitimin uzun vadede derse yönelik tutumları olumlu etkileyebildiği söylenebilir.

Araştırmada öğrencilerin tutumlarında cinsiyet ve evinde bilgisayar bulunma durumu değişkeni açısından anlamlı farklıık bulunmamıştır. Kız öğrencilerin tutum puanları erkeklere göre daha yüksek olmasına rağmen istatistiksel açıdan bir farklılık oluşmamıştır. Sınıf ortamında bilgisayar destekli materyal kullanımı bilgisayarı olan ve olmayan öğrencilerin tutumlarını aynı düzeyde etkilemektedir. Benzer bir biçimde Ovalı (2011) bilgisayar destekli Türkçe öğretiminin akademik 
başarıya olan etkisini incelediği çalışmasında da cinsiyetin ve bilgisayara sahip olup olmama durumunun okuduğunu anlama başarısı üzerinde etkisi olmadığı sonucuna ulaşmıştır. Topçu (2009) cinsiyetin bilgisayar tutumu üzerindeki etkisini araştırdığı meta analiz çalışmasında Türkiye'de yapılan 47 araştırmanın etki büyüklüğünü incelemiştir. Araştırma sonucunda cinsiyetin bilgisayar tutumuna yönelik etkisinde erkekler lehine sonuca ulaşmıştır. Buna göre erkeklerin kızlara göre bilgisayara yönelik tutumları daha olumlu olmakla birlikte tutumlar arasındaki fark anlamlı düzeyde değildir. Bu durum araştırma sonuçlarıyla uyuşmaktadır. Artık teknoloji hayatın her alanında yer aldığı için teknolojik araçlar, çocuktan yetişkine cinsiyet ayrımı olmaksızın her kesim tarafından kullanılmaktadır.

Ana dili eğitimi öğrencilerin akademik ve gündelik hayatlarında etkili olduğu gibi tüm yaşam becerilerinde de etkilidir. Değişen/gelişen toplum ve dünya şartlarına uyumlu bireyler yetiştirmek, aranılan 21. yüzyıl becerilerini geliştirmek konusunda Türkçe derslerinin önemi büyüktür. Ne öğretileceği ve bunun nasıl öğretileceğine ilişkin temel değişiklikler kaçınılmazdır. Teknolojik araçlara ulaşım günümüzde oldukça kolaylaşmıştır. Teknolojinin kullanım alanlarının sadece sosyal medya ve iletişimle ile sınırlı kalmaması, eğitim sistemi içindeki yerinin çeşitlenmesi vazgeçilmezdir. Bununla birlikte önem kazanan diğer husus öğrencilerin teknolojiyi sadece tüketici olarak kullanamamaları gerektiğinin farkına varmalarını sağlamaktır. Teknolojinin öğrenme, öğrenmeyi düzenleme içerisindeki yeri konusunda ve teknolojinin içinde üretici olarak var olma süreçlerinde öğrencilere yol gösterilmelidir. Web 2.0 araçlarının kullanımı bu süreçte önemlidir. Bu araştırmada Web 2.0 araçları materyallerle birlikte kullanılmış ve 6. sınıf öğrencilerinin Türkçe dersine yönelik tutumlarına etkisi incelemiştir. Farklı sınıf düzeylerinde, farklı araçlarla yeni çalışmalar yapılarak daha detaylı sonuçlara ulaşılabilir.

\section{Kaynaklar}

Apperson, J. M., Laws, E. L. ve Scepansky, J. A. (2006). The impact of presentation graphics on students' experience in the classroom. Computers and Education, 47(1), 116-126.

Balcı, A. (2011). Sosyal bilimlerde araştırma yöntem, teknik ve ilkeler. Ankara: PegemA Yayıncılık.

Benzer A. (2017). Dijital çağda öğretim teknolojileri ile Türkçe eğitimi. Ankara: TTGV.

Büyüköztürk, Ş. (2001). Deneysel desenler. Ankara: PegemA Yayıncılık.

Büyüköztürk, Ş. (2011). Sosyal bilimler için veri analizi el kitabı. Ankara: PegemA Yayıncılık.

Byrne, R. (2009). The effect of web 2.0 on teaching and learning. Teacher Librarian, 37(2), 50-53.

Creswell, J. W. (2003). Research design: qualitative, quantitative, and mixed method approaches (2 ${ }^{\text {nd }}$ ed.). Thousand Oaks, California: Sage Publications.

Creswell, J. W. (2005). Educational research: planning, conducting, and evaluating quantitative and qualitative research. Columbus: Pearson Merril Prentice Hall.

Creswell, J. W. ve Clark, P. (2007). Designing and conductingthe mixed methods reader. Thousand Oaks: Sage Publications. 
Conole, G. ve Alevizou, P. (2010). A literature review of the use of web 2.0 tools in higher education. 7 Kasım 2017 tarihinde https://www.heacademy.ac.uk/knowledge-hub/literature-review-use-web-20-toolshigher-educationsayfasından erişilmiştir.

Dikmen, M. ve Tuncer, M. (2018). Bilgisayar destekli eğitimin öğrencilerin akademik başarıları üzerindeki etkisinin meta-analizi: Son 10 yılda yapılan çalışmaların incelenmesi. Türk Bilgisayar ve Matematik Eğitimi Dergisi, 9(1), 97-121.

Elmas, R. ve Geban, Ö. (2012).21. Yüzyıl öğretmenleri için Web 2.0 araçları. International Online Journal of Educational Sciences, 4(1), 243-254.

Erişen, Y. ve Çeliköz, N. (2007). Eğitimde bilgisayar kullanımı. Demirel, Ö. ve Altun, E. (Editörler). Öğretim teknolojileri ve materyal tasarımı, 1. Baskı, Ankara: PegemA Yayıncılık.

Filiz, O. ve Kurt, A. A. (2018). Günümüz web 2.0 teknolojileri geleceğin güçlendirilmiş çocukları için neler sunuyor? Buket Akkoyunlu, Aytekin İşman ve Hatice F. Odabaşı (Ed.). Eğitimde Teknoloji Okumaları (s.312-323). Ankara: TOJET.

Gençoğlu, T. (2013). Geometrik cisimlerin yüzey alanları ve hacmi konularının öğretiminde bilgisayar destekli öğretim ile akıllı tahta destekli öğretimin öğrenci akademik başarısına ve matematiğe ilişkin tutumuna etkisi. Ankara: Gazi Üniversitesi Eğitim Bilimleri Enstitüsü, Yayınlanmamış yüksek lisans tezi.

Güven, G. ve Sülün, Y. (2012). Bilgisayar destekli öğretimin 8. sınıf fen ve teknoloji dersindeki akademik başarıya ve öğrencilerin derse karşı tutumlarına etkisi. Türk Fen Eğitimi Dergisi, 9(1), 68-79

Kablan, Z., Topan, B. ve Erkan, B. (2013). Sınıf içi öğretimde materyal kullanımının etkililik düzeyi: Bir metaanaliz çalışması. Kuram ve Uygulamada Eğitim Bilimleri, 13(3), 1629-1644.

Karasar, N. (2005). Bilimsel araştırma yöntemi. Ankara: Nobel Yayın Dağıtım.

Knapp, L. R. ve Glenn, A. D. (1996). Restructuring schools with technology. Boston: Allyn and Bacon.

Koç, Y., Şimşek, Ü. ve Has, C. (2013). Işık Ünitesinin Öğretiminde Bilgisayar Animasyonlarının Etkisi. Muş Alparslan Üniversitesi Fen Bilimleri Dergisi, 2, 145-156.

Koşar, E., Yüksel, S., Özkılıç, R., Avcı, U., Alyaz, Y. ve Çiğdem, H. (2003). Öğretim teknolojileri ve materyal geliştirme. Ankara: PegemA Yayıncılık.

Lu, J., Lai, M. ve Law, N. (2010). Knowledge building in society 2.0: Challenges and opportunities. M. S. Khine and I. M. Saleh. (Ed.). In New science of learning: Computers, cognition and collaboration in Education (pp. 553-567). Newyork, Springer.

Lowry, R. B. (1999). Electronic presentation of lectures effect upon student performance. University Chemistry Education, 3(1), 18-21.

Milli Eğitim Bakanlığı (2018). Türkçe dersi öğretim programı (ilkokul ve ortaokul 1, 2, 3, 4, 5, 6, 7 ve 8.sınıflar). Ankara: Devlet Kitapları Müdürlüğü.

Olgun, A. (2006). Bilgisayar destekli fen bilgisi öğretiminin öğrencilerin fen bilgisi tutumları, bilişüstü becerileri ve başarılarına etkisi. Eskişehir: Osmangazi Üniversitesi, Fen Bilimleri Enstitüsü, Yayımlanmamış yüksek lisans tezi.

O'Reilly T. (2007). What is web 2.0: design patterns and business models for the next generation of software. Communications \& Strategies, 65 (1), 17-37.

Ovalı, T. (2011). Ilköğretim 8. sınıf Türkçe dersinde bilgisayar destekli öğretimin öğrencilerin anlama becerisine etkisi. Sakarya: Sakarya Üniversitesi, Eğitim Bilimleri Enstitüsü, Yayınlanmamış yüksek lisans tezi.

Önder, R. (2015). Biyoloji dersinde akıllı tahta kullanımının öğrencilerin akademik başarılarına, akıllı tahta kullanımına ve derse yönelik tutumlarına etkisi. İzmir: Dokuz Eylül Üniversitesi Eğitim Bilimleri Enstitüsü, Yayınlanmamış yüksek lisans tezi.

Rıza, E. T. (2000). Eğitim teknolojisi uygulamaları ve materyal geliştirme. İzmir: Anadolu Matbaası. 
Sevim, O. ve Sayır, F. (2017). Türkçe derslerinde akıllı tahta ile yapılan konuşma becerisi etkinliklerinin öğretmen ve öğrenci görüşlerine göre incelenmesi. Uluslararası Türk Eğitim Bilimleri Dergisi, (8), 160172.

Şen, M. (2013). Ilköğretim birinci kademe ingilizce öğretiminde akıllı tahta kullanımının öğrenci başarısına etkileri. İstanbul: İstanbul Üniversitesi, Eğitim Bilimleri Enstitüsü, Yayınlanmamış yüksek lisans tezi.

Şimşek, N. (1998). Öğretim amaçıı bilgisayar yazılımlarının değerlendirilmesi. Ankara: Siyasal Kitabevi.

Tataroğlu, B. (2009). Matematik öğretiminde akıllı tahta kullanımının 10. sınıf öğrencilerinin akademik başarıları, matematik dersine yönelik tutumları ve öz-yeterlilik düzeylerine etkileri. İzmir: Dokuz Eylül Üniversitesi Eğitim Bilimleri Enstitüsü, Yayınlanmamış yüksek lisans tezi.

Tayfa, H. (2018). Etkileşimli tahtanın Türkçe dersinde kullanımının ortaokul öğrencilerinin akademik başarı ve tutumlarına etkisi. Kütahya: Kütahya Dumlupınar Üniversitesi, Eğitim Bilimleri Enstitüsü, Yayınlanmamış yüksek lisans tezi.

Tercan, i. (2012). Akıllı tahta kullanımının öğrencilerin fen ve teknoloji dersi başarı, tutum ve motivasyonuna etkisi. Konya: Necmettin Erbakan Üniversitesi Eğitim Bilimleri Enstitüsü, Yayınlanmamış yüksek lisans tezi.

Tiryaki, A. (2014). 6. sınıf kuvvet ve hareket ünitesinde akıllı tahta kullanımının öğrenci başarııına ve tutumuna etkisi. İstanbul: İstanbul Üniversitesi, Eğitim Bilimleri Enstitüsü, Yayınlanmamış yüksek lisans tezi.

Topçu, P. (2009). Cinsiyetin bilgisayar tutumu üzerindeki etkisi: Bir meta analiz çalışması. İstanbul: Marmara Üniversitesi, Eğitim Bilimleri Enstitüsü, Yayınlanmamış yüksek lisans tezi.

Ünal, F. T. ve Köse, M. (2014). Türkçe dersine yönelik tutum ölçeği geliştirilmesi: Bir geçerlilik ve güvenirlik çalışması. Bartın Üniversitesi Eğitim Fakültesi Dergisi, 3(2), 233-249.

\section{Extended Abstract \\ Introduction}

Technology has become one of the indispensable elements of human life in recent years. Technological developments have not remained limited to a single area, but have started to be employed in every discipline and all kinds of learning. It is impossible for the education system whose basic subject is human not to be affected from this process. In the last decade, rapid developments have taken place in this field and computer-assisted education has become a method used in almost every school. In addition, it has become a field of competence requiring to be aware of developments in technology and to use these technologies for their purposes. In the 2018 Turkish Curriculum (TC), this issue was emphasized unlike other programs.

Moreover, some of the objectives stated in the curriculum are directed to the development of students' skills required to have access to printed materials and multimedia resources, to organize information, question, use and produce it (TÖP, 2018: 7). In order for students to acquire these skills and to achieve the objectives of the program, they need to use and experience technology in educational environments. One of the most frequently used technological tools in education is computer. In this context, it can be said that computers are widely used in the field of education. In this respect, computer-assisted instruction (CAI) has been a topic that has been addressed in the learning process. When the definition of the computer-assisted instruction is examined, it is seen that the greatest emphasis is put on the use of computer in learning-teaching environments and in school activities (Demirel, Seferoğlu and Yağcl, 2001); to reinforce learning-teaching occurrences (Şimşek,1998); to make students better understand a topic or a concept or to reinforce what has been learned before (Yalın, 2003, s.165). The quality and variety of the materials selected to be used in instructional environments can be conducive to the teaching and learning process from several respects.

Though the Turkish language course seems to be consisted of four basic language skills and grammar, in fact it includes a more comprehensive multi-faceted process. Although all of the comprehension and narrative skills have common characteristics, they have some different qualities. Different methods and techniques must be used to focus on these qualities in the learning environment. Many materials such as methods and techniques enhance the learning process. In the Turkish Curriculum (2018), diversity as a learning-teaching approach has been addressed. When the studies in the relevant literature were examined, it was found that there are a limited number of studies on Turkish education and computer assisted teaching processes. Given the limited amount of research, the current study aiming to investigate the effect of the use of computer-assisted materials on sixth grade students' attitudes towards the Turkish language arts course is 
believed to make some contributions to the field in today's world where education and technology are intertwined.

Method

In the current study investigating the effect of the use of computer-assisted materials on students' attitudes towards the Turkish language arts course, the quasi-experimental pretest-posttest control group design; one of the qualitative research methods, was employed. The study group of the current research is comprised of 72 sixth- grade students attending a public middle school in the city of Kütahya in 2017-2018 school year. In order to determine the students' attitudes towards the Turkish course, the "Scale of Attitudes towards the Turkish Course" developed by Topçuoğlu Ünal and Köse (2014) and to elicit the students' opinions about the application process a semi-structured interview form were used in the current study.

The data were collected in three stages. Prior to the application, the experimental and control group students were administered the "Scale of Attitudes towards the Turkish Course". The subjects in the curriculum were taught to the experimental group students by using computer-assisted materials for 10 weeks. At the end of the application, the "Scale of Attitudes towards the Turkish Course" was re-administered to the experimental and control groups. In the third stage, interviews were conducted with the experimental group students to elicit their opinions about the process.

\section{Results and Discussion}

As a result of the analyses conducted, it was found that there is a significant difference between the posttest mean scores of the experimental and control groups. A significant difference was found between the experimental group students' pretest mean attitude score (96.48) and posttest mean attitude score (112.51). There is no significant difference between the control group students' pretest mean attitude score and posttest mean attitude score. Both the experimental group and control group students' attitude scores were found to be not varying significantly depending on the variables of gender and having one's own computer. The experimental group students stated that the lessons taught through these materials were more enjoyable and effective. 